Science in the Service of Children 1893-1935 


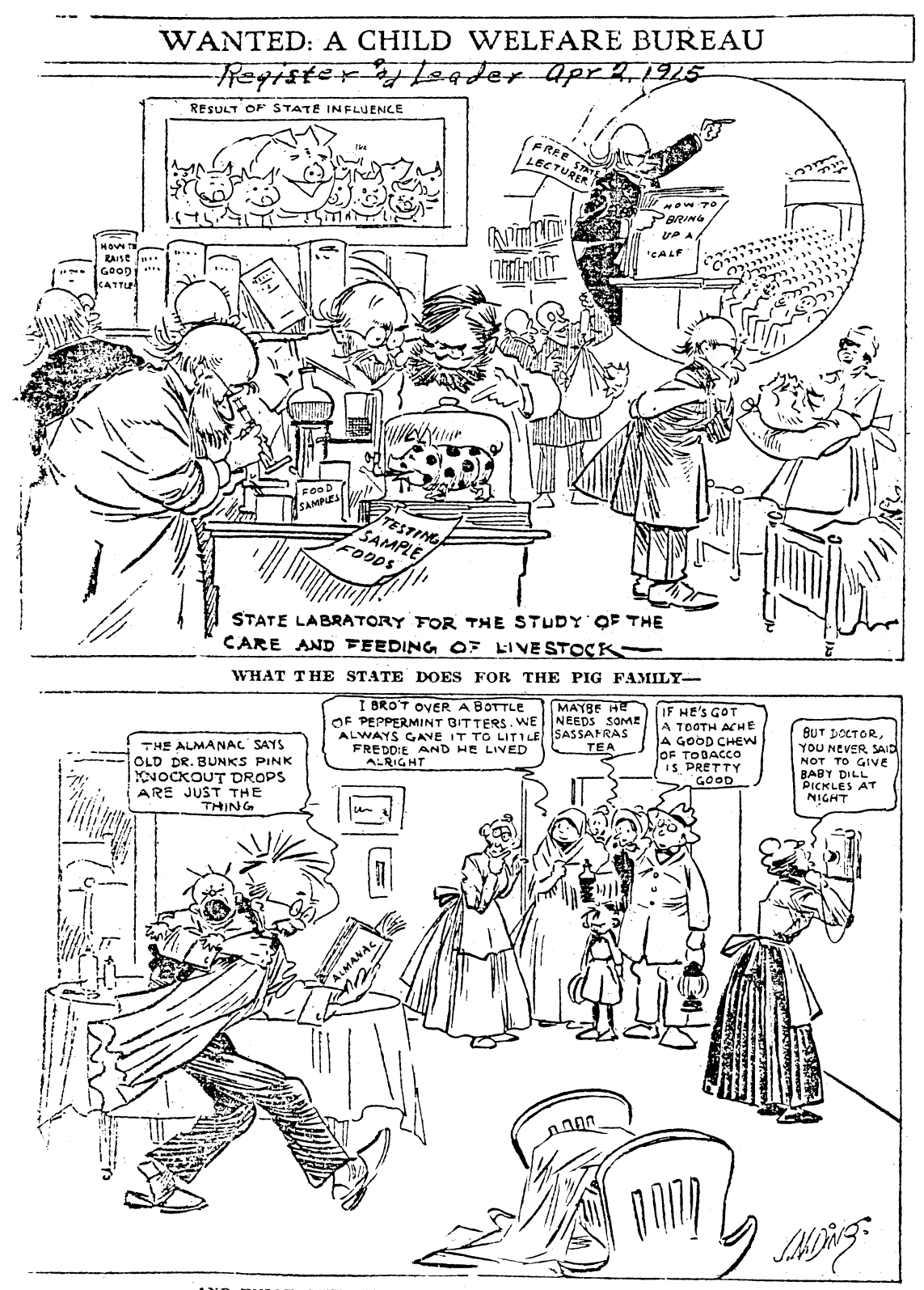

AND WHAT TFE STATE, DULS FOK THE HEMAY FAMLY

Courtesy of the J. N. "Ding” Darling Foundation. 


\section{Science in the Service of Children, 1893-1935}

Alice Boardman Smuts

With the assistance of Robert W. Smuts, R. Malcolm Smuts, Barbara B. Smuts, and P. Lindsay Chase-Lansdale

Yale University Press

New Haven and London 
Published with assistance from the Louis Stern Memorial Fund.

frontispiece: From the Cora Bussey Hillis Scrapbook Inventory, Iowa State Historical Society, Iowa City. Courtesy of the J. N. "Ding” Darling Foundation.

Copyright $(9) 2006$ by Alice Boardman Smuts. All rights reserved.This book may not be reproduced, in whole or in part, including illustrations, in any form (beyond that copying permitted by Sections 107 and 108 of the U.S. Copyright Law and except by reviewers for the public press), without written permission from the publishers.

Set in Garamond and Stone Sans types by The Composing Room of Michigan, Inc. Printed in the United States of America.

Library of Congress Cataloging-in-Publication Data Smuts, Alice Boardman.

Science in the service of children, 1893-1935 / Alice Boardman Smuts ; with the assistance of Robert W. Smuts ... [et al.].

$$
\text { p. } \mathrm{cm} \text {. }
$$

Includes bibliographical references and index.

ISBN-13: 978-0-300-I0897-2 (alk. paper)

ISBN-IO: 0-300-I0897-4 (alk. paper)

I. Child development-Research-United States-History. 2. ChildrenResearch—United States-History. 3. Child welfare-United States-

History. 4. Child rearing-United States-History. I. Smuts, Robert W. II. Title.

$$
\begin{aligned}
& \text { HQ787.85.S68 2005 } \\
& \text { 362.7'0973' 0904I-dc22 }
\end{aligned}
$$

2005023925

A catalogue record for this book is available from the Library of Congress and the British Library.

The paper in this book meets the guidelines for permanence and durability of the Committee on Production Guidelines for Book Longevity of the Council on Library Resources.

IO 98765432 I 
For my grandchildren, Robert Malcolm Smuts, Jr., and Felicia Alice Smuts.

And in memory of Ethel Sturges Dummer, Cora Bussey Hillis, Julia Lathrop, and Grace Abbott, who decided to find out what children really need, and for the men and women who have kept their quest alive. 
